\title{
Experiment and experience in the phototextual projects of Sophie Calle
}

Born in 1953, Sophie Calle is both a writer and a photographer, and rarely one without the other. This double focus is accommodated in two main forms. The first, and the one that usually appears first, is the installation exhibited in an art gallery or museum, where photos hung at eye level or sometimes simply leaning against a wall are juxtaposed with framed printed texts. But Calle has also found a rewarding outlet in the form of book publications based on the same kind of text-photo juxtaposition and, given the scope and objectives of this particular volume of essays, it is above all on the published work that I focus here. By virtue of being compacted into and redistributed across a sequence of pages, the published work tends all the more strongly to bear out the description of herself that Calle is said to favour: that of 'narrative artist' (which neatly sidesteps the more frequently bestowed label of 'conceptual artist'). ${ }^{1}$ Calle's work has become renowned for the stimulating and often controversial ways in which it crosses the boundary lines between public and private, detachment and involvement, life and art. In crossing such lines, Calle's work comes to bear a high degree of self-implication, a quality it shares with the work of many other contemporary artists, such as Christian Boltanski, Annette Messager and Orlan. What does it mean to be 'implicated in' one's work, as opposed, say, to being 'expressed by' it? In order to address this question, we first need to set Calle's work in its historical context: that of the shift from the modernist project of art to a postmodernist art of the project.

The term 'project' may be used to describe the activities providing the raw material of Calle's installations and published works. A project involves thinking up and then setting up a situation that will be allowed to 
run its course under certain conditions. The external boundaries of the situation will be defined by preordained limits of time and/or space, while its internal dynamics will be defined by a further set of ground rules or protocols. The photographer remains acutely aware of limits, for delimitation accounts for every photograph, being a condition at once imposed (by the rectangular edges of the shot when first taken, edges themselves dictated by the format of the film in the camera) and assumed, changed into something chosen (by framing, trimming, cropping, etc.). In this respect, Calle may well be a postmodernist, but in her work thus far she has remained steadfastly pre-digital, an artist who likes to play with evidentiality rather than virtuality or computer-manipulated imagery.

As something 'set up' or staged, the project-situation is artificial, a quality reflected in Calle's use of terms such as rituel (ritual) or pseudoenquête (pseudo-inquiry) to describe certain of her projects. By the same token, more or less all of her projects may also be described as experiments: experiments run not with a view to testing any particular hypothesis, but, far less teleologically, in order to 'see what happens'. This I take to be a suddenly resonant phrase as applied to Calle, given both her status as a photographer ('to see. ..') and her self-definition as a 'narrative' artist ('. . .what happens'). I shall argue in this chapter that, for Calle, 'seeing what happens' always includes seeing what happens to herself, tracking her own experience as primed and prompted by the context of the experiment. Her 'own' experience here is, we might say, an 'experimental experience', an experience of the kind made accessible in and through the promotion of what Celia Lury calls 'experimental individualism'. Conceived as a contemporary alternative to the norm of 'possessive individualism', this is a mode in which the individuality, identity or biography of the person can be prosthetically disassembled and reassembled using various forms of technological mediation. ${ }^{2}$ As Lury herself remarks, in a comment that sounds tailor-made to evoke the case of Sophie Calle: 'the prosthetic biography requires significant new forms of authorisation and, in this respect, the image is combining with narrative to produce techniques of the self in new ways' (p. 24).

Calle's most compelling projects have typically taken the form of experiments in approaching the other, in 'entering into the life' of the other, as she herself put it when writing in La Filature about the private detective who tailed her around Paris on 16 April 1981 - a detective she had persuaded her mother to hire for this purpose as part of another engineered, experimental situation. ${ }^{3}$ The book includes not only her own notes taken over the course of the day as she was being followed, but a copy of the 
detective's report and reproductions of the photos he had been instructed to take as evidence of his subject's movements and activities while under surveillance. Thus the auto-portrait is counterpointed by a kind of alloportrait. Calle's own notes record how she recurrently found herself wondering whether the detective felt attracted to her: a show of affect which nods knowingly towards the romanticism of the mass-market photo-roman. Contrary to the scripts and scenarios of the photo-roman, however, there is never any question in La Filature of wanting actually to meet the man. The experience of feeling a 'personal' connection with him, to the point where the day in question is described by Calle with hollow poignancy as 'notre journée' (p. 118) (our day), is a product of the experiment, an 'experimental experience', which, as such, remains tied to the provisional, prosthetic identity of the woman under surveillance, and cannot therefore be transported outside the limits and protocols of the experiment.

By constantly making us unsure about the face value of her textual and photographic statements, Calle seems to encourage in those who read and view her work a sense of its own incipient fictionality, even where its most overt claims are documentary or, in photographic terms, indexical. At the same time, however, it continues to sound as though it could still be 'true': the effect of truth, whether autobiographical or ethnographic in its generic force, is not cancelled out. We are thus left suspended, uncertain. There are many reasons one could adduce for both the suspicion of fictionality in Calle's work and the sense of its ultimately uncertain status. I would like to suggest here that one of the most pervasive triggers of both responses is the recurrent instance of what I have chosen to call 'experimental experience'. Experimental experience takes the form of feelings, emotions, reactions, etc., which are not so much in and of an underlying self as signs announcing what Celia Lury, echoing Roland Barthes, calls the 'advent', indeed the 'adventure', of oneself as other (p. 76). And this sense of a self coming into view as other, at a remove from what it was, is easily - and often accurately - construed as a process of generating a fictional character out of autobiographical material. The principle of uncertainty is restored, however, if, along Barthesian lines, the strategy of 'experimental experience' is understood to offer a more self-protective way of reconstituting the division between public and private. In other words, might this strategy not provide Calle with a technique for fulfilling what was also Barthes's desire as a writer in La Chambre claire: 'Je veux énoncer l'intériorité sans livrer l'intimité' (I want to utter interiority without yielding intimacy) ? $^{4}$ Another way of making the same point might be to say that the subject of 
'experimental experience' in La Filature is not in fact the one I referred to earlier as the woman under surveillance, but, more precisely, the woman who knows she is under surveillance, the woman with the upper hand. In ethnographic terms, the 'observer' has merged with the 'participant'. What I call 'experimental experience', therefore, may well involve stepping into a role, but does not escape the self-implication of the one playing that role. And, ultimately, the romantic script which Calle finds herself reading aloud, and which superimposes an image of vulnerability onto that of the woman with the upper hand, must probably be read as something that joins the role to the player, something that is not played out in a purely ironic spirit. More generally, this is one example of the way experimental experience implicates Calle herself as the subject of certain fantasies, indeed as the subject of a certain kind of madness.

Since the late 1980 , Calle has explored more open, empathic and collaborative ways of 'entering into the life' of the other, notably by using interviews in order to garner raw material for the textual component of certain projects. Surprisingly, however, this more recent vein was illustrated by only one of the eleven phototextual projects included in 'Doubles-jeux', a major exhibition of Calle's work shown in 1998 at the Centre National de la Photographie in Paris. A boxed set of seven books representing the exhibited works, and bearing the same title, was published simultaneously by Actes-Sud. ${ }^{5}$ The exhibition was itself the fruit of a kind of meta-project inspired by the activities of Calle's fictional double, Maria Turner, the eccentric character from Paul Auster's novel, Leviathan (1992). Eight of the component works of the exhibition correspond, as Calle herself puts it, to rituals that Auster 'borrowed' from her to shape the character of Maria. Calle also used the exhibition as an opportunity to produce two new works based on rituals attributed to Maria for which she herself had not been the direct inspiration. Finally, Calle took this 'double-play' or 'double-ploy' one stage further by inviting Auster to do with her whatever he wished for a period of up to one year, as though she were no longer just a real model for a fictional character, but his own fictional creation. As she explains in the text repeated at the start of each of the seven volumes of the book Doubles-jeux, Auster declined her invitation, preferring instead to send her some 'personal instructions' for the improvement of life in New York. The resulting project eventually yielded Gotham handbook - the one component of Doubles-jeux that reflects, albeit in a rather jaundiced manner, the new, ethically correct Calle.

This, perhaps, is an appropriate point at which to offer a justification 
for the fact that, in a book about women's writing in French in the 1990s, I should have chosen to devote the remainder of this essay to an analysis of Suite vénitienne and L'Hôtel, two works by Calle first exhibited and published in the 1980s. I leave aside, for the time being, my contention that, in engaging with the other on a non-collaborative or intrusive basis, Calle's 1980 os projects raise questions that were once more being strongly echoed in the late 1990s. What concerns me here is the question, or questioning, of temporal location. The project documented in La Filature took place in 1981 but did not become available as a published document until 1998, when it appeared as a component of the book Doubles-jeux. Somewhat differently, Suite vénitienne and L'Hôtel already existed in book form and were recycled in Doubles-jeux. There is no doubt, however, that, for many readers and spectators previously unfamiliar with Calle, all components of the exhibition and book had a 'firstness' - and indeed a sense of late $1990 \mathrm{~s}$ contemporaneity - about them. Moreover, the 'doubleness' of Doubles-jeux arises not only through the phototextual interplay of document and fiction, experience and experiment, 'Sophie Calle' and 'Maria Turner', but through a temporal interplay of past and present. This occurs most obviously at the chronological level, where the inclusion of new work ensures that Doubles-jeux cannot be pigeon-holed into the comfortable format of the 'retrospective'. But it can also be seen to occur within individual components of the work. For example, in the book Doubles-jeux, the 1998 versions of both Suite vénitienne and L'Hôtel show changes in textual and photographic content, as well as general layout, when compared with the 'original' versions. Similar changes can even be noted when one moves from the 'original' French paperback version of Doubles-jeux to the larger, more lavishly produced English-language version, Double Game, published as a single hardback volume. ${ }^{6}$ Different book formats will affect what Calle decides to select from her own archive and how she decides to present that selection, just as the different physical settings offered by different museums and galleries will affect the precise content and layout of her exhibitions. Calle's enthusiasm for demonstrating the permutability of her previously published or exhibited phototextual sequences indicates clearly that, for her, as for numerous other contemporary artists (and, increasingly, writers), there is no such thing as a definitive, unproblematically date-bound, realisation of a given project.

The phototextual projects that yielded Suite vénitienne and L'Hôtel take the form of essentially furtive attempts to engage with the life of a singular or serial other. One insight into this furtiveness is offered by Jean 
Baudrillard when discussing Suite vénitienne in a 1994 interview: 'Pas de psychologie, mais une façon énigmatique d'entrer dans la vie de l'autre, non pas au sens où vous la violez, mais au sens où vous en êtes le secret' (No psychology, but an enigmatic way of entering into another's life, not in the sense that you violate it, but in the sense that you are its secret). ${ }^{7}$ 'Being the other's secret' is a form of words prompted by Baudrillard's theory of seduction, but at the same time a euphemism meaning that the other remains unaware of being followed or spied on. The boundary lines separating private from public, and life from art, are variously crossed in most of Calle's work, but nowhere more dramatically, intrusively and therefore controversially, than in her projects of the early 1980 s. These projects are not necessarily motivated by a humanist impulse of 'being-towards-theother', as advocated by a Levinas or a Ricœur, and they are therefore not necessarily set up in any expectation of finally 'meeting' the other. Furtiveness is necessitated, if never fully justified, by the idea of entering into the life of another person without their knowledge, obliquely, by indirect means. In so doing, Calle also typically lays herself open to the advent of the aleatory within the situation established by her own ground rules. What I have called 'experimental experience' often results from striking interactions of choice and chance.

In turning now to Suite vénitienne and L'Hôtel, my analysis will focus not only on the 'furtive' nature of Calle's entry into the life of the other, but on the way she represents the modalities of her own self-implication in each project. I shall also try to highlight how Calle's propensity for thinking through photography impacts on the experimental and experiential dimensions of either project.

Suite vénitienne consists of the photographic and textual record, packaged as an illustrated diary, of two weeks Calle spent in Venice in 1980, first of all hunting down a man she had first met in Paris, and subsequently shadowing him. In so doing, she plays out what Whitney Chadwick calls 'an elaborate transference of agency, appropriating the "male gaze" and producing the woman, traditionally the object of others' looks in public, as the viewing subject'. ${ }^{8}$ Venice itself, of course, is a charged site, guaranteed to intensify whatever is at stake in the project for Calle herself. By a happy coincidence, carnival time is approaching and masks are very much in evidence. In order to conceal her identity from her prey, Calle too has decided to disguise herself for the duration of the project by wearing a blonde wig (she assures us that in reality she is a brunette).

The whole artistic and literary mythology of Venice infects Calle from 
the outset, and indeed affects very directly the way she represents her own self-implication in this project. Calle's more personal comments in her diary are, rather unusually, given prominence and added urgency by being set in italics. One of the first occurrences of such italicised text is also one of the most dramatic: 'Arrivée place Saint-Marc, je m'assieds contre une colonne. Je regarde. Fe me vois aux portes d'un labyrinthe, prête à me perdre dans la ville et dans cette histoire. Soumise' (I arrive at Piazza San Marco and sit against a column. I look around. I see myself at the gates of a labyrinth, ready to get lost in the city and in this story. Submissive). ${ }^{9}$ Calle imagines she is on the threshold of a loss of self, an entering-in and giving-in to the labyrinthine destiny whose parameters are a city and a story. The city and story in which one volunteers to lose oneself, or to advene as other, are thus the site of an unusually intense 'experimental experience', a kind of danger zone. Indeed, the reflexive doubling of 'Je me vois...' (I see myself) briefly distinguishes experimental subject from experiential subject, the overseer from the undergoer, only to confirm at the same time that the two positions are co-referential. Given this image of seeing oneself, and the fact that the figure of self advening as other has its roots in one of Barthes's comments from La Chambre claire concerning our reactions to photographs of ourselves, it is clear that Calle's propensity for thinking through photography strongly informs the question of 'experimental experience' - as both envisaged and enacted.

Still two days before she eventually catches sight of the man called Henri B., Calle finds herself struggling to keep experimental experience at an appropriate remove, a safe distance:

12h 30. Je vais me promener sur la plage du Lido. Fe pense à lui et à cette phrase de Proust: 'Dire que j'ai gâché des années de ma vie, que j'ai voulu mourir et que j'ai eu mon plus grand amour, pour une femme qui ne me plaisait pas, qui n'était pas mon genre.'

Fe ne dois pas oublier que je n'éprouve aucun sentiment amoureux pour Henri B. Ces symptômes, l'impatience avec laquelle j'attends sa venue, la peur de cette rencontre, ne m'appartiennent pas en propre. (p. 57)

(12:30 p.m. I take a walk along the beach of the Lido. I think about him and about that sentence of Proust: 'To think that I've wasted years of my life, that I wanted to die and had my greatest love for a woman who gave me no pleasure, who was not my type?.

I must not forget that I have no feelings of love toward Henri B. These symptoms - my impatience as I await his arrival, my fears about our meeting - don't really belong to me.) 
Her impatience and fear, she tries to persuade herself, are 'symptoms' that do not belong to her as such. By this, she presumably means that these symptoms are no more than effects produced by the experimental situation, little more than fictional implants. (Curiously, it is of course a fiction, Proust's Un Amour de Swann, that helps her see this.) By attempting to distance and disavow any feelings of amorous involvement with Henri B., the subject perhaps forgets that the experiencer is co-referential with the experimenter, and that co-reference implies both discontinuity and continuity. Baudrillard has argued tirelessly that Calle's work, as exemplified in the case of Suite vénitienne, has left psychology behind, abandoning the 'degraded' alterity of inter-subjective encounters and altercations in favour of something called 'pure' alterity (p. 147). It is no accident that Baudrillard hardly ever discusses the work as a concrete realisation. By contrast, what interests me is precisely the trace, at certain crux moments, of something like 'psychology' in Calle's efforts to manage the notion of experimental experience. Paradoxically, this trace is nowhere more evident than in her very efforts to escape 'psychology'. Psychology, or inter-subjectivity, determines here that, both before and during the time she first glimpses Henri B., both before and during the time he identifies and confronts her in a Venice street, the story launched by the experimental project is, as Calle writes in the penultimate sentence of the diary framing the photographs of Suite vénitienne, "notre histoire' (p. 107) (our story). Irony swarms around this phrase, but never quite manages to sting it to death, even when we learn through the good offices of Baudrillard writing some fourteen years after the event that, due to legal objections lodged on behalf of the filmmaker Henri B., Calle was in fact obliged before publishing or exhibiting her work to return to the scene of her potential crime and restage all her photos featuring Henri B. and his female companion, but now with two stand-ins (p. 145). To be privy to such information is to appreciate that the temporal staggering of Calle's work from its initial completion as project to its eventual, multiple and frequently remixed realisations in exhibited and published form can be more complex than at first appears to be the case.

What does effectively cancel out the story qua 'our' story is the decision to discontinue the experiment. 'Our' story will have no future beyond the limits of the project, outside the space of disguise, carnival and labyrinth, which proved so conducive to the cultivation of experimental experience. Such, it seems to me, is the import of Calle's parting words in Suite vénitienne: 'Je le photographie une dernière fois alors qu'il franchit l'enceinte de la gare.Je n'irai pas plus loin. Il s'éloigne, je le perds de vue.Après 
ces treize jours passés avec lui, notre histoire s'achève. 10 h 10. Je cesse de suivre Henri B.' (p. 107) (I photograph him one last time as he passes through the station gate. I shall go no further. He walks away, I lose sight of him. After these last thirteen days with him, our story comes to an end.10:10 a.m. I stop following Henri B.).

First published as a book in 1984, L'Hôtel is the phototextual record of a project undertaken by Calle, again in Venice, and once more around carnival time, between February and March 1983. This book too, moreover, is presented in the form of an illustrated diary. And yet another common feature with other works of the early 1980 s is that L'Hôtel opens with a brief outline of the nature of the project behind the book. Here, Calle explains how, in February 1981, she finally managed to find a temporary three-week job as a chambermaid in the 'Hotel C... Having been entrusted with twelve rooms on the fourth floor, she then tells us how she proceeded to examine the 'personal effects' (in context, a very resonant phrase) of the occupants of those rooms, furtively observing in a detailed way 'des vies qui me restaient étrangères' (lives that remained foreign to me). ${ }^{10}$ The precise details anticipate a key quality of the diary, for it is written not only day by day, but room by room. In ascribing sequences of days to each room visited within the delimited experimental field of three weeks and twelve rooms, Calle invites us to perceive the structure of both the book and the project in terms of a grid. As for the accessibility of the rooms in question, what better way to gain indirect entry into the lives of others than to get oneself hired as a hotel chambermaid? These others will be available to Calle only through their 'personal effects' and through a variety of 'signs' left behind in their rooms. Present effects, absent causes; signs unaccompanied, and in a sense unburdened, by the makers or leavers of those signs. Hence the delicate balance of intimacy and distance in the assertion of having observed in detail 'lives that remained foreign to me'. Hence also, perhaps, our uncertainty as to whether, for Calle, this enduring strangeness represents a frustration or a kind of ideal.

Just how Calle carried out her inquiry is something we only discover as we read on. Each day, we soon learn, she concealed a camera and a tape recorder in her bucket, smuggling these into the various rooms she was due to clean. This is how she came to take the photos and compile the often detailed on-the-spot observations that would merge into the form of an illustrated diary. The diary reveals how Calle not only observed what was on display, but searched in drawers and rummaged through suitcases, frequently removing articles and spreading them on the floor or bed in order 
to photograph them as if they constituted some kind of forensic evidence. She delves into diaries, letters, passports and other identity papers, often recording whole pages verbatim for later transcription into her own diary and eventual exhibition and publication. Another group of signs that catches her eye, and her lens, is that made up of crumpled bedsheets, items of clothing strewn across chairs or hung in wardrobes, and shoes. What these signs have in common for Calle is suggested when, on her last working day at the hotel, she reflects on the sight of a dented pillow. Before viewing the pillow symbolically as 'un signe d'adieu' (a sign of farwell), she sees in it 'l'empreinte arrondie d'une présence' (p. 36) (the rounded imprint of a presence). In other words, she reads it semiotically as an index, a sign whose relationship with its object is one of causal, sequential or spatial contiguity. Indexicality, of course, has long been recognised and theorised as the most fundamental sign-quality of the photograph insofar as the camera mechanically registers a configured influx of light reflected by the objects placed before it. The pillow, like the bedsheets, and to a lesser extent like the shoes and items of clothing Calle constantly snaps, is a bodygraph. The body-graph provides another example of Calle not just taking photos, but thinking photographically.

How applicable is the notion of 'experimental experience' to the case of L'Hôtel? Calle is obviously once more disguised, and, to the extent that the employee to whom she hands over her responsibilities is described in the text as a 'vraie femme de chambre' (p. 172) (real chambermaid), she admits to having herself been a false chambermaid. But does her experience within this experiment draw upon that of a chambermaid? Here, it would seem, the role of chambermaid is basically a pretext, a cover: it's the only way to get into the rooms in the first place. Calle does occasionally advene as other, the most notable example being when, having received a 'nice smile' from a man in the corridor outside Room 30 (one of 'her' rooms), she records her reaction as follows: 'Fabrice en personne? Pour la première fois, j'imagine durant quelques secondes un client se penchant sur mon sort de femme de chambre et me proposant de tout lâcher, de partir avec lui. A Paris peut-être. ..' (p. 109) (Fabrice in the flesh? For the first time, I briefly imagine a patron taking an interest in my plight as a chambermaid and inviting me to drop everything and go away with him. Maybe to Paris. ..). Here, a very conventional romantic script involving knight on horseback and damsel in distress has implanted itself in the subject as chambermaid. In most other respects, the experiential dimension seems to build on the opportunity that being a chambermaid has 
opened up for Calle herself (for the observer rather than the participant). We recognise a similar counterpoint between recording and reacting to that found in the preceding projects, cast here as an alternation of inventory, description and transcription on the one hand, and more personal comments on the other. But in this case the personal comments are mainly expressions of attraction and aversion, of differing reactions to different guests on the basis of the signs they leave around or the stories those signs suggest. This could be, but need not be, the experience of a chambermaid. Thus the notion of an advent of self as other works in a rather different way in L'Hôtel.

In this particular project, our image of Calle as both experimenting subject and experiencing subject is at least partly constructed out of a series of parallels or dédoublements that align her with the other as absent guest. Indeed, she seems in many ways to share the very 'strangeness' of that other as represented in his or her 'personal effects'. Calle's inventories are reflected in the guests' inventories, her keeping of a diary in their keeping of diaries, her chambermaid mask in their carnival masks. Most of these dédoublements seem to point to a shared characteristic of obsessive behaviour. Obsession and mysteriousness combine most pointedly in the final section of the book. This corresponds to the only day, her last, that Calle spent cleaning Room 29 while it was occupied by someone whose few personal effects leave their owner difficult to identify even in terms of gender. (This in a context where the gender of absent guests is usually identified by Calle at a glance.) Having looked around the bathroom, Calle returns to the bedroom, and opens the wardrobe to find no items of clothing, just a quantity of objects, which she proceeds to lay on the bed in order to photograph them. In her diary she makes a list of all the items in question. After the third item, she comes onto a series of articles, "chacun maniaquement isolé dans un sachet en plastique' (p. 172) (each manically separated in a plastic bag): an SNCF sheet, a sponge, two hairbrushes, and so on. She concludes: 'Tout est ordonné, empaqueté, aseptisé. Ici pas de ménage à faire, ne seraient les dérangements occasionnés par ma propre fouille' ( $p$. 172) (Everything is ordered, wrapped up, sterilised. No tidying up to do here, except to conceal the disruption caused by my own search). Though the notion of sterilising or sanitising has no real echo in Calle's work, those of ordering and packaging do. In this case, for example, her own resort to listing tends not only to record, but in some degree to repeat, something of the manic quality she herself identifies in the other.

This guest's obsessive isolation of objects is illustrated in the use of 
plastic bags, but above all, perhaps, in the image of a box hermetically sealed with Scotch tape. In the original edition of L'Hôtel, Calle includes the photo of the box alongside five other photos of equal proportions. The pattern made by the Scotch tape on the visible face of the box appears to reproduce the pattern made by the photos on the page. It is also, of course, a dédoublement suggesting a parallel of some kind between the other's mania and Calle's own art. Boxes, grids, rectangles, and right angles do indeed pervade her work, structurally and thematically. However, whereas the other's mania is ultimately figured in an act of binding, sealing and concealing, Calle's art works in virtually the opposite direction. This basic contrast should warn us against pushing the parallels too far. In this respect, it is interesting that, in the new edition of L'Hôtel published in 1998 (part of a boxed set, as it happens), Calle chose to extract the photo of the box from its original six-pack and present it on a page of its own (p. 173). The surface of the box no longer doubles the surface of the page, and the manic other (implied to be anal-retentive) no longer doubles the experimental artist. The box now represents something like a full stop, bringing to an end this last section of the book, set on the last day of Calle's period of employment in the Hotel C. Accordingly, I shall use it to bring my own analysis to as full a stop as I can manage.

There is no vanishing point in this photo. The bright glow in the background hints at a sunlit window but is in fact no more than the light from Calle's flashbulb being reflected back by the mirrors on the panels of the wardrobe. Likewise, the eye is drawn towards the focal object, the box, only to be turned back as it meets an unyielding surface head on. The photo locates us in an entre-deux: we're inside the walls of the room, but outside the walls of the box. The photo itself has been made possible by another kind of room or chamber or box. We are not trapped so much as poised in this entre-deux, for this is the space in which Calle the artist can only work successfully by achieving a balance between intrusion, the fact of being in the room, and discretion, the fact of being willing to stay outside the box, willing to accept that these lives will ultimately remain 'foreign'. Such discretion belongs to a more general rhetoric, at once behavioural, textual and pictorial, in Calle's work, of délestage, or generalised reluctance. Reluctance, for example, to speculate, extrapolate, spell out, or say more than needs to be said (right down to her abbreviations of names: 'Henri B.', the 'Hotel C.'). The photo as repositioned in the 1998 edition of L'Hôtel is about suspending operations, about going so far and no further, and about photographic distance as one of the strongest forms of aesthetic tension 
between 'so far' and 'no further' (this is also the space Christine Angot explored in the 1990s through her evolving series of autofictions). The repositioned photo affirms the quality of photography often described by terms like 'cold', 'mechanical', 'minimal', 'merely constative'. What I am calling 'reluctance' proceeds, then, from the thought of photography. Accordingly, few statements may be considered more photographically thoughtful than the very last textual segment of L'Hôtel, where Calle, in a conclusion that could hardly be more minimal, writes: 'Le vendredi 6 mars 1981, à 13 heures, mon service à l'hôtel C. s'achève' (p. 172) (Friday 6 March 1981, 1:oo p.m.: my duties at the Hotel C. come to an end).

In engaging with the other on a non-collaborative or intrusive basis, Calle's 1980 s projects, as recycled in the late 1990s, raise questions that were once more being strongly echoed at that time. One thinks in the realm of photography of Luc Delahaye's book, L'Autre, consisting of photos taken in the Paris Métro using a hidden camera; photos which Delahaye provocatively admits to be 'stolen' insofar as French law states that everyone owns their own image. It comes as no surprise, moreover, that this book should include an afterword by Jean Baudrillard, and that Baudrillard should set Delahaye's photos in a context beyond all 'moral anthropology', beyond all 'forced figuration', defined as 'représentation abusive de ce qui ne veut pas être représenté' (abusive representation of that which does not want to be represented). ${ }^{11}$ One thinks also in the literary realm of the work of Christine Angot, whose ongoing project, as embodied in texts like Les Autres, Sujet Angot and L'Inceste, produces complex and controversial intersections of auto-biographical material and fictional techniques. Such intersections are fascinating and unsettling in equal measure, for they leave the works in question, alongside those of Calle and Delahaye, on the edge of the morally, legally and, therefore, aesthetically acceptable. Few works more tellingly measure the extent, and potentially the cost, of the contemporary artist's will to self-implication.

\section{Notes}

1 For Calle's self-definition as 'narrative artist', see the text to be found at www.cnpphotographie.com/expo/atelier/archive/sophie/index.html (Anon.).

2 See Celia Lury, Prosthetic Culture: Photography, Memory and Identity (London: Routledge, 1998), pp. 23-4.

3 Sophie Calle, La Filature, in A suivre, book IV of Doubles-jeux (Arles: Actes Sud, 1998), p. 116. Translations are either my own or adapted from existing translations.

4 Roland Barthes, La Chambre claire (Paris: Cahiers du cinéma/Gallimard/Seuil, 
1980), p. 153. Lury (p. 78) discusses this quotation, but in a slightly different context to that operative here.

5 See note 3.

6 Sophie Calle, Double Game (London: Violette, 1999).

7 Jean Baudrillard and Marc Guillaume, Figures de l'altérité (Paris: Descartes, 1994), p. 148.

8 Whitney Chadwick, 'Three artists/three women: Orlan, Annette Messager and Sophie Calle', Sites, 4(1) (2000), 111-17 (113).

9 Sophie Calle, Suite vénitienne, Book IV of Doubles-jeux, p. 44.

10 Sophie Calle, L'Hôtel, Book V of Doubles-jeux, p. 9.

11 Jean Baudrillard, 'Transfert poétique de situation', in Luc Delahaye, L'Autre (London: Phaidon, 1999), unpaginated. 